\title{
Appendiceal faecolith: a radiological finding not to be missed
}

\author{
Gareth Martel, ${ }^{1}$ Julia Martin ${ }^{2}$
}

${ }^{1}$ Ulster Hospital, Belfast, UK ${ }^{2}$ Department of Vascular Surgery, Royal Hospital Belfast, Belfast, UK

\section{Correspondence to}

Gareth Martel,

g.martel.04@aberdeen.ac.uk

Accepted 4 April 2015

\section{DESCRIPTION}

A 25-year-old man presented with a short history of sudden onset right iliac fossa pain. Examination revealed tenderness maximal at McBurney's point with localised peritonism. Routine investigation included a plain abdominal X-ray.

As can be seen in the image, the X-ray revealed a calcified density overlying the right iliac wing in keeping with a faecolith (figure 1). Open appendicectomy was subsequently performed, with findings of an inflamed perforated appendix containing a $21 \mathrm{~mm}$ faecolith. Histology confirmed acute appendicitis.

The presence of a faecolith is a common finding at appendicectomy, ${ }^{1}$ and has been shown to be associated with an increase in risk of appendiceal perforation. $^{2}$ In this particular case, the faecolith remained within the appendix; however, the radiological finding is an important consideration at the time of surgery. A retained faecolith can inadvertently be left within the abdominal cavity leading to an increased risk of abscess formation. ${ }^{3}$ It is therefore important to perform a thorough examination of the peritoneal cavity in cases of perforated appendicitis to exclude this.

\section{Learning points}

- Calcified faecoliths within the appendix may be visible on plain $\mathrm{X}$-ray.

- The presence of a faecolith within the appendix increases the risk of perforation.

To cite: Martel G, Martin J. BMJ Case Rep Published online: [please include Day Month Year] doi:10.1136/ bcr-2015-210161
- It is essential that any appendiceal faecolith is removed at the time of surgery to reduce the risk of abscess formation.

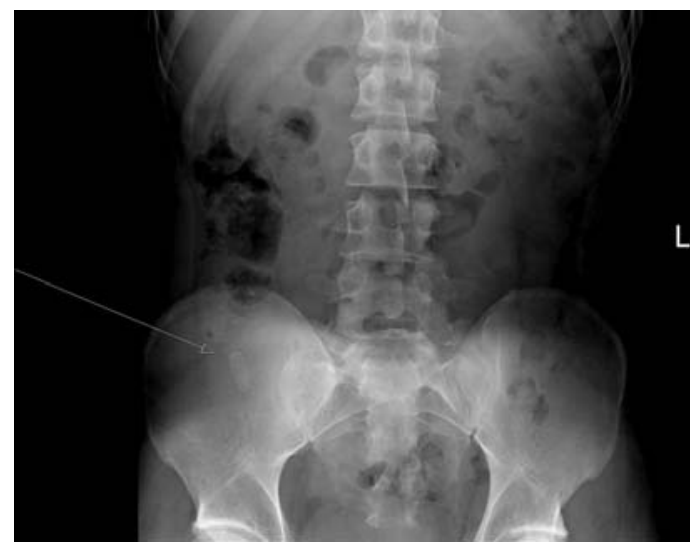

Figure 1 Plain abdominal X-ray clearly showing the presence of a faecolith within the appendix.

While many faecoliths will not be visible on plain X-ray, if one is evident, as in this case, it is an important finding that needs to be considered at the time of appendicectomy.

Contributors GM performed the literature review, composed the case report, and obtained and formatted the images. JM reviewed the draft report and assisted in completion of the final draft.

Competing interests None declared.

Patient consent Obtained.

Provenance and peer review Not commissioned; externally peer reviewed.

\section{REFERENCES}

1 Ulukaya Durakbaşa C, Taşbaşi I, Tosyali AN, et al. An evaluation of individual plain abdominal radiography findings in pediatric appendicitis: results from a series of 424 children. Ulus Travma Acil Cerrahi Derg 2006;12:51-8.

2 Singh JP, Mariadason JG. Role of the faecolith in modern-day appendicitis. Ann R Coll Surg Eng/ 2013;95:48-51.

3 Knight $\mathrm{O}$, Brar R, Clark J. Retained faecolith: an avoidable complication of laparoscopic appendicectomy. BMJ Case Rep 2013;2013:pii: bcr2013201255.

Copyright 2015 BMJ Publishing Group. All rights reserved. For permission to reuse any of this content visit http://group.bmj.com/group/rights-licensing/permissions.

BMJ Case Report Fellows may re-use this article for personal use and teaching without any further permission.

Become a Fellow of BMJ Case Reports today and you can:

- Submit as many cases as you like

- Enjoy fast sympathetic peer review and rapid publication of accepted articles

- Access all the published articles

- Re-use any of the published material for personal use and teaching without further permission

For information on Institutional Fellowships contact consortiasales@bmjgroup.com

Visit casereports.bmj.com for more articles like this and to become a Fellow 